\title{
Pharmacognostic Evaluation and Analgesic Efficacy of Ethanolic Extract of Euphorbia dracunculoides L.
}

\author{
Umbreen Khattak', Rehman Ullah², Shafqat Ali Khan*1, Barkatullah', Sami Ullah² and Saima²
}

\section{Umbreen Khattak, ${ }^{1}$ Rehmanullah, ${ }^{2}$ Shafqat Ali Khan, ${ }^{* 1}$ Barkatullah, ${ }^{1}$ and Sami Ullah ${ }^{2}$}

'Department of Botany, Islamia College University, Peshawar, PAKISTAN.

${ }^{2}$ Department of Botany, University of Peshawar, PAKISTAN.

\section{Correspondence}

Shafqat Ali Khan, Department of Botany, Islamia College University, Peshawar, PAKISTAN.

Tel.: +923439620689

E-mail: shafqatbotany3@gmail.com

History

- Submission Date: 23-04-2017;

- Review completed: 18-05-2017;

- Accepted Date: 04-07-2017

DOI : 10.5530/pj.2017.5.102

Article Available online

http://www.phcogj.com/v9/i5

Copyright

(C) 2017 Phcog.Net. This is an openaccess article distributed under the terms of the Creative Commons Attribution 4.0 International license.

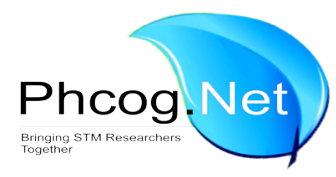

\begin{abstract}
Background: Euphorbia dracunculoides $\mathrm{L}$ is available in market in raw form. It is used by people for the treatment of warts, snake bite and epilepsy. Present study is about Euphorbia dracunculoides L. belonging to the family Euphorbiaceae, comprises pharmacognostic study, physiochemical analysis and their pharmacological efficacy. Materials and Methods: The macroscopic study was carried out through sensory organs like size, shape, texture etc. Physiochemical analysis was carried out through proper procedure from relevant literature, and analgesic activity was done through proper method by following literature. Results: Macroscopic study showed that the plant is an annual herb, stem is branched from the base, yellow green at the bottom and light green at the top, glabrous, smooth, contains white latex, its leaves are sessile, alternate, dark green, simple, stipulated, sub-acute or acute at the apex and entire margin. Root is yellowish in colour, conical in shape, smooth texture, downward in position. Powder drug study which was performed revealed various structures. Phytochemical screening includes both qualitative and quantitative analysis which was carried out indicated the presence of carbohydrates, proteins, saponins, sterols, alkaloids, phenolic compounds, glycosides, flavonoids and tannins. Proximate analysis showed proteins, crude fat, crude fibre, carbohydrates, moisture contents and ash. Elemental analysis revealed the presence of macro and micronutrients i-e $\mathrm{Na}, \mathrm{Zn}, \mathrm{Mg}$ and $\mathrm{Fe}, \mathrm{Cu}, \mathrm{Ag}$ and $\mathrm{Au}$. Analgesic effect was dose dependent. Plant extract showed maximum inhibition of writhing $1.66 \pm 0.32(96.61 \%)$ at 300 $\mu \mathrm{g} / \mathrm{ml}$. Conclusion: The pharmacognostic study, physiochemical analysis and their pharmacological efficacy is helpful in the standardization of drug.
\end{abstract}

Key words: Pharmacognostic evaluation, Whole plant, Euphorbia dracunculoides L. macroscopic study, Powder drug study, Physiochemical analysis, Analgesic activity.

\section{INTRODUCTION}

Pharmacognosy signifies the importance of medicinal plants as cost-effective health factor of biodiversity and also their preservation and sustainable use (Rahman et al., 2004). The knowledge of certain plants and their unique qualities has been passed on through the generations to ultimately reach us. ${ }^{1}$ Natural products derived from plants have been traditionally important in prevention of illness and homeopathic treatment. They are also contained active ingredients for the production of health care products. ${ }^{2}$ Medicinal plants contain some bioactive organic compounds i-e carbohydrates, steroids, tannins, flavonoids, alkaloids and terpenoides, which provide specific physiological action on the human body. Information of the chemical constituents of plants is advantageous because such information will be significant for the production of complex chemical substances. ${ }^{3-4}$ Medicinal plants possess enormous potential as beneficial drugs for human beings. Certain chronic and infectious diseases can be effectively treated using the substances present in these plants. ${ }^{5}$ However, lack of authentic documents and strict quality control has been detrimental to the

recognition and approval of traditional medicine in developed countries. To standardize and identify the plant material used in Traditional medicine we must invest in pharmacognostic and phytochemical studies. If the quality of the product is without blemish, it will be easier to ensure reproducible quality of herbal medicine which will ensure safety and effectiveness. ${ }^{6}$

Plants are considered basic nutritional source as they contain protein, carbohydrates, fats, oils, minerals, vitamins, and water, which are obligatory for growth and development in human and animals. These phytochemicals have been considered of crucial nutritional importance in the prevention of chronic disease such as cardiovascular disease, cancer, and diabetics. $^{7-8}$ In human beings the macro and micro elements play a role in biochemical process. Plant secondary metabolites and minerals have a great role in metabolism. $\mathrm{Fe}, \mathrm{Ca}, \mathrm{Mn}, \mathrm{Mg}, \mathrm{Zn}$ and $\mathrm{Cu}$ are present in small amount in the hairs of Breast cancer patients. ${ }^{9}$ Analgesic drugs are pain relievers and generally act on the central and peripheral

Cite this article : Khattak WU, Rehmanullah, Khan SA, Barkatullah, and Ullah S. Pharmacognostic Evaluation and Analgesic Efficacy of Ethanolic Extract of Euphorbia dracunculoides L.. Pharmacog J. 2017;9(5):644-53. 
nervous system. Unlike anesthetics, which eliminate sensation, analgesics simply ease pain in the host. Traditional ethno-medicine used to relieve pain is a potential source for discovering novel anti-inflammatory, antipyretic and analgesic drugs. Natural products are a rich source of chemical substances with beneficial therapeutic capabilities. ${ }^{10}$

\section{MATERIALS AND METHODS}

\section{Collection and preservation}

Euphorbia dracunculoides was collected from the southern districts of Khyber Pakhtunkhwa, cleaned and jumbled thoroughly, dried in shade. A specimen was mounted in kept on a herbarium sheet, given a voucher number and kept in the department of Botany. It's macroscopic and microscopic characteristics were studied. An electric grinder was used to thrash the dried plants into powder and then stored in an air-tight bottle that protects it from hostile climate, insect attacks, molds and moisture. Physiochemical analysis is also carried out on a part of this powder and biological studies are performed on the rest.

\section{Morphological observation Macroscopic Study}

The macroscopic observation of Euphorbia dracunculoides was carried out by organoleptic method, we analyzed the shape, size, odor, color, petiole, phylotaxis, lamina, surface, taste, Apex, Type, leaf margins, stipule and venation of the leaf, also analyzed colour, habit, taste, odor, size, surface, shape, branching, position, latex, texture, surface in stem, In root we analyzed size, shape, odor, taste, color, position, texture, surface and rootlets. ${ }^{11}$

\section{Microscopic Study \\ Powder microscopy}

The organoleptic characteristics of Euphorbia dracunculoides in powder form were studied such as microscopial characteristic odor, color and taste. Following Wallis, (2005), who carried out powder drug study.

\section{Procedure}

Whole plant shade dried at $25^{\circ} \mathrm{C}$ for 7 days and grounded using electric grinder. Powders of dried parts were used for the observation of the microscopic characters. A pinch of fine powder was taken on a glass slide treated with chloral hydrate solution and iodine solution, then observed under a microscope using different objective lenses for observation of different anatomical structures, which were then photographed.

\section{Elemental analysis}

Elemental analysis of powder from the selected parts was carried out with atomic absorption spectrophotometry for the following trace and heavy metals. ${ }^{12}$

\section{Preliminary qualitative phytochemical analysis}

Phytochemical analysis was done by following ${ }^{13-17}$

\section{Test for reducing sugars}

- Fehling's test: A few drops of Fehling's reagent were added separately to ethanolic extracts of Euphorbia dracunculoides taken in test tubes. A red color appeared once the mixture was heated, thereby proving the presence of reducing sugars.

- Benedict's test; A few drops of Benedict's solution was added to ethanolic extract of E. dracunculoides taken in separate test tubes. The presence of reducing sugars was confirmed by the appearance of a brick red color.

\section{Killere killiani test for steroidal Glycosides}

- Glacial acetic acid was used to separately treat $4 \mathrm{ml}$ of extract along with $5 \% \mathrm{FeCl}_{3}$ and a few drops of concentrated $\mathrm{H}_{2} \mathrm{SO}_{4}$. A bluish green color appeared in the upper layer and a reddish brown appeared at the seam of the two liquids which confirmed the presence of steroidal glycosides.

\section{Confirmative test for tannins}

- Ferric chloride $\left(\mathrm{FeCl}_{3}\right)$ test: $\mathrm{A}$ few drops of $\mathrm{FeCl}_{3}$ solutions were added separately to extract solution of the selected plant. The color transition from dark green to blue-black indicated the presence of Phenol heads, while the complete blue color meant hydrolysable tannin. The presence of condensed tannins in the test samples was confirmed by the green color.

\section{Detection of Alkaloid}

Hydrochloric acid was used to dissolve the ethanolic extracts separately, which were then filtered, and the filtrates were used for different tests for Alkaloid detection.

Dragondroff's test: A red precipitate was observed once the filtrate was treated with Dragondroff's reagent, which proved the presence of Alkaloids.

Hager's test: Yellow precipitation occurred once the Filtrates were treated with saturated picric acid solution, which is typical for Alkaloids.

Wagner's test: A reddish brown color appeared once the filtrates were treated with iodine in Potassium Iodide solution (Wagner's reagent), hence proving Alkaloid presence.

\section{Saponins confirmation}

Froth test: Distilled water was used to dilute the ethanolic extracts of the plant. A froth appears once they were vigorously shaken for more than five minutes, thus proving the presence of Saponins.

\section{Detection of Triterpenes and Phytosterols}

Salkowski's test: Chloroform was used to dissolve the extracts and the solution was then filtered. A few drops of concentrated $\mathrm{H}_{2} \mathrm{SO}_{4}$ were added to the filtrate, the solution was shaken and then kept still. Triterpenes were indicated by a yellow color while phytosterols were indicated by a red color in the lower layer.

\section{Detection test proteins \& aminoacids}

Xanthoproteic test: A few drops of concentrated $\mathrm{HNO}_{3}$ were added to $2 \mathrm{ml}$ of extract solution. A yellow color appears once it is heated. The color soon turns orange.

\section{Biuret test}

- $2 \mathrm{ml}$ of Biuret reagent was added to the test sample and a violet color is observed which represents the presence of protein.

- Ninhydrin test: To the plant extract solution $0.2 \%$ Ninhydrin solution was added resulted appearance of violet coloration which indicated the presence of protein.

\section{Detection of Oil}

\section{Spot test}

- A tiny amount of powdered drug was pressed between the folds of the filter paper which resulted in a translucent oily stain which represents the presence of fixed oil and fats. 


\section{Detection of flavonoids}

\section{Alkali test}

- The test samples were treated with $\mathrm{NaOH}$ solution. A strong yellow color is observed. If dilute acid is added, it decolorizes which proves Flavonoid presence.

\section{Lead acetate test}

- If a yellow color is observed once lead acetate solution is added to the test samples, it means flavonoids are present.

\section{Quantitative chemical analysis}

Sterols, Saponins, Tannins and Alkaloids can be determined by quantitative analysis of the whole plant using standard method of ${ }^{16-18}$

\section{Alkaloids determination Materials required}

Ethanolic extracts, acetic acid, filter paper, beaker, balance, water bath

\section{Procedure}

Harborne method ${ }^{16}$ was used to determine the quantity of Alkaloids in whole plant extract. $100 \mathrm{ml}$ of $10 \%$ acetic acid was added to 2 grams of ethanolic extract in a beaker, which was then covered and kept for four hours. The mixture was then concentrated to one-fourth of its original volume using a water bath. A precipitate formed once concentrated ammonium hydroxide was added drop by drop to the solution. Pre weighted (W1) Whitman filter paper was used to collect the precipitate. Dilute ammonium hydroxide was used to wash it. The filter paper containing the residue was dried and weighed (W2).

The amount of Alkaloid was calculated as such:

$$
\begin{aligned}
& \text { Amount of alkaloid }(\mathrm{mg} / \mathrm{g})=\frac{\mathrm{x}}{\text { Weight }} \\
& \text { \% Alkaloid }=\frac{\mathrm{x}}{\text { Weight of sample }} \times 100 \\
& \text { Where } \\
& \quad \mathrm{X}=\text { Weight of alkaloids }=\mathrm{W} 2-\mathrm{W} 1 \\
& \mathrm{~W} 1=\text { Weight of filter paper } \\
& \text { W2 }=\text { Weight of filter paper }+ \text { ppt }
\end{aligned}
$$

\section{Saponin determination Material required}

A separatory funnel, balance, filter paper, water bath, $5 \%$ sodium chloride solution, n-butanol, Ethanolic extract and Dimethyl ether.

\section{Procedure}

Obadoni and Ochuko ${ }^{18}$ method was used to determine the quantity of Saponin. $20 \mathrm{ml}$ of distilled water was used to dissolve 2 grams of an ethanolic extract of Euphorbia dracunculoides, which was then moved to a 250 milliliter separating funnel. The mixture was shaken vigorously after a further addition of $20 \mathrm{ml}$ diethyl ether. After draining out the layer of ether, $60 \mathrm{ml}$ of $\mathrm{n}$-butanol was mixed with the aqueous layer which resulted in the precipitation of saponin. Pre weighted (W1) Whitman filter paper was used to collect the Saponin, washed thoroughly with $10 \mathrm{ml}$ of $5 \%$ aqueous $\mathrm{NaCl}$ solution. An oven at $40^{\circ} \mathrm{C}$ was used to dry the precipitate to constant weight (W2). The Saponin content and the initial weight of the sample were measured and calculated as given below:

$$
\text { Amount of saponins }(\mathrm{mg} / \mathrm{g})=\frac{\mathrm{x}}{\text { Weight of sample }}
$$

$$
\begin{aligned}
& \text { \% saponins }=\frac{\mathrm{x}}{\text { Weight of sample }} \times 100 \\
& \mathrm{X}=\text { Weight of saponin }=\mathrm{W} 2-\mathrm{W} 1 \\
& \mathrm{~W} 1=\text { Weight of filter paper } \\
& \mathrm{W} 2=\text { Weight of filter paper }+ \text { residue }
\end{aligned}
$$

\section{Tannins determination}

\section{Material required}

Ethanolic extracts, Whitman filter paper, lead acetate solution, balance, hot air oven, sulphuric acid, water bath

\section{Procedure}

Van-Buren and Robinson, ${ }^{17}$ was used to determine the $\%$ tannins in the plant extract.To get tannins first we took 2 gram extract of Euphorbia dracunculoides then dissolved it in distilled water $(75 \mathrm{ml})$, after dissolution the solution was then filtered with Whitman filter paper. Solution of lead acetate was added to it in order to get lead- tinnate precipitate. $20 \mathrm{ml}$ of water was added to the residue, dilute $\mathrm{H}_{2} \mathrm{SO}_{4}$ was also added to the solution which removed lead sulphate. The solution was filtered through pre weighted Whitman filter paper (W1) and tanins were collected. The filter paper was dried in oven (at $60 \mathrm{C}$ ). Filter paper was weighed again. $\%$ tannins were calculated by using the formula.

$$
\begin{aligned}
& \text { Amount of Tannins }(\mathrm{mg} / \mathrm{g})=\frac{\mathrm{x}}{\text { Weight of sample }} \\
& \% \text { Tanins }=\frac{\mathrm{x}}{\text { Weight of sample }} \times 100 \\
& \text { Where } \quad \mathrm{X}=\text { Weight of tannins }=\mathrm{W} 2-\mathrm{W} 1 \\
& \mathrm{~W} 1=\text { Weight of filter paper } \\
& \mathrm{W} 2 \text { = Weight of filter paper+ residue }
\end{aligned}
$$

\section{Sterols determination \\ Materials}

Whitman filter paper, Ethanolic extracts, petroleum ether, $10 \%$ potassium hydroxide solution, Balance, flasks, water bath, reparatory funnel.

\section{Procedure}

In this process, $75 \mathrm{ml}$ of distilled water and $10 \% \mathrm{KOH}$ were added to 2 grams of extract. The process changed the chlorophylls contents into chlorophyllins (water soluble salt). It was then treated thrice with petroleum ether $(75 \mathrm{ml})$ in a separating funnel. First, the flask was weighed (W1), ether portion was collected in the flask and then it was placed in a water bath. When it became concentrated and dried, the flask was placed in a desiccator for cooling. The flask was weighed again (W2) and \% sterol was calculated using the following formula (Huang et al., 2010)

$$
\begin{aligned}
& \text { Amount of sterols }(\mathrm{mg} / \mathrm{g})=\frac{\mathrm{x}}{\text { Weight of sample }} \\
& \% \text { sterols }=\frac{\mathrm{x}}{\text { Weight of sample }} \times 100
\end{aligned}
$$

Where

$$
\begin{aligned}
\mathrm{X} & =\text { Weight of sterols }=\mathrm{W} 2-\mathrm{W} 1 \\
\mathrm{~W} 1 & =\text { Weight of flask } \\
\mathrm{W} 2 & =\text { Weight of flask }+ \text { residue }
\end{aligned}
$$


Nutritional analysis

Determination of Moisture

Apparatus

Desiccator, Electric oven, Electric balance, petri dish with lid.

\section{Procedure}

2 gram of powder was taken in petri plate then weighted it (W1). The petri plate was covered with lid partially; the petri plate was then placed in oven $\left(105 \mathrm{C}^{\circ}\right)$ for 4 to 6 hours in order to remove moisture. Then place the petri dish in desiccator for cooling for 30 minutes. After that, weight the petri plate again. ${ }^{19}$

\section{Calculation}

(\%) Moisture $=\frac{\mathrm{W} 1-\mathrm{W} 2}{\text { Weight of the sample }} 100$

\section{Determination of Ash}

Equipment's required

Desiccator, burner, Muffle furnace, Blow pipe, Crucible, Electric balance,

\section{Procedure}

2 gram of sample powder was taken in a sterilized crucible (W1). Before placing in muffle furnace it was first burnt with burner with the help of blow pipe. Then place it in furnace $\left(550^{\circ} \mathrm{C}\right)$ for many hours. The furnace was then turned off and the color of sample changed into grayish white. Then the crucible was transferred into dessicator in order to cool. Weight it again (W2). The \% Ash was calculated by using the following formula. ${ }^{20}$

\section{Calculation \\ $\%$ Ash $=(\mathrm{W} 2-\mathrm{W} 1) \times 100$ Wt. of sample \\ $\mathrm{W} 1$ = Weight of empty crucible \\ W2 $=$ Weight of crucible + Ash \\ Determination of Crude Protein by Micro Kjeldahl Method.}

\section{Reagents}

$4 \%$ boric acid solution, $40 \% \mathrm{NaOH}, 0.1 \mathrm{~N}$ standard $\mathrm{HCl}$ solution, concentrated sulphuric acid, catalyst $\left(7 \mathrm{gm} \mathrm{K}_{2} \mathrm{SO}_{4}, 0.5 \mathrm{~g} \mathrm{CuSO} \mathrm{CH}_{2} \mathrm{O}\right.$ and $0.3 \mathrm{~g} \mathrm{HgO}$ ).

\section{Indicator}

i. Methyl red, 0.25 percent in $95 \%$ Ethanol

ii. Methylene blue, $0.2 \%$ in $95 \%$ ethanol. Mix(i) and (ii) in the ratio of 3:2

\section{Apparatus}

Volumetric flask, pipette, Kjeldahl flask, burette, digestion and distillation apparatus etc.

\section{Procedure}

$0.3 \mathrm{~g}$ of the powder sample was taken in KJELDAHL flask. $7 \mathrm{ml}$ of conc. $\mathrm{H}_{2} \mathrm{SO}_{4}$ and $1.5 \mathrm{~g}$ of catalyst were added to the flask. It was mixed thoroughly by spinning the flask. After this, it was digested in digestion flask on the heater till the solution may became clear. The process continued for 30 minutes. When the digestion completed, the heater was turned off in order to cool the solution. The digest was then diluted with $50 \mathrm{ml}$ distilled water in a volumetric flask. $5 \mathrm{ml}$ of the digest was then taken by using pipette. The solution was then transferred into distillation tube. Then, $5 \mathrm{ml}$ of $40 \%$ Sodium hydroxide solution was added through the funnel. Distillate was distilling for five minutes. $20 \mathrm{ml}$ of $4 \%$ boric acid solution was taken in a flask and some drops of indicator were added into the flak and then, collected the distillate. During distillation, the color changed from pink to blue.

After that, the distillate was titrated against $0.1 \mathrm{~N} \mathrm{HCl}$ taken in a burette till the pinkish color restored. The reading of the volume of $\mathrm{HCl}$ was noted and $\%$ protein was calculated. ${ }^{21}$

\section{Calculation}

$\%$ protein $=\frac{(\mathrm{S}-\mathrm{B})^{\prime} \mathrm{N} \text { of acid' } 0.014^{\prime} \text { dilution' }^{\prime} 100}{\text { Wt. of sample' aliquot of digest taken for distillation }}$

Where

$$
\begin{aligned}
\mathrm{S} & =\text { Sample titration reading } \\
\mathrm{B} & =\text { Blank titration reading } \\
0.14 & =\text { Millequivalent of nitrogen }
\end{aligned}
$$

\section{Determination of fat or ether extract:}

Apparatus: Water bath, petroleum ether (B.P 40-60C ${ }^{\circ}$ ), Soxhlet extraction apparatus, Extraction Thimble (Whatman).

\section{Procedure}

For the extraction of crude fat, the Soxhlet apparatus was used. Here in this process, first $2 \mathrm{gm}$ moisture free sample powder was taken in a clean thimble. The thimble was than plugged with cotton then placed it in extractive tube. Weighted the $250-\mathrm{ml}$ round bottom flask then added petroleum ether solvent up to $1 / 3^{\text {rd }}$ of the flask after that fixed it in the extractive tube. Turned on burner and tap water to flow. Run the apparatus for 3 to 4 hours. After that, thimble was removed from the tube; the flask was then placed on the water bath to heat up and to remove the moisture. The flask was then placed in oven at $105 \mathrm{C}^{\circ}$ in order to dry for $1 \mathrm{hr}$. It was allowed to cool and weighted again (W2).

Fats percentage was then calculated by the following equation ${ }^{22}$

$\%$ fat $($ Ether extract $)=\frac{\mathrm{x}}{\text { Weight of sample }} \times 100$

Where $\quad \mathrm{X}=$ Weight of the fats $=\mathrm{W} 2-\mathrm{W} 1$

$\mathrm{W} 1=$ Weight of the empty flask

W2 = Weight of the empty flask + sample after evaporation of solvent

\section{Crude fibre determination:}

Reagents: Asbestos, Ethyl Alcohol, Petroleum ether, Sodium hydroxide (2\%), $\mathrm{HCl}(2 \%)$

\section{Apparatus}

Muffle furnace, crude fibre extraction apparatus, suction pump, oven, electric balance, Gooch crucible, funnel, beaker, filter paper or cotton cloth

\section{Procedure}

2 gram of sample powder was taken in a beaker and added $200 \mathrm{ml}$ of $2 \%$ $\mathrm{NaOH}$ kept on water bath for 30 minutes till it boils then filtered it with a cloth. The residue was then transferred into the beaker and add $200 \mathrm{ml}$ of $2 \% \mathrm{HCl}$ keep on water bath and boil for 30 minutes. Filter it with a cloth again and the remaining residue was then washed with $200 \mathrm{ml}$ hot water in order to remove the acid. The residue was then transferred into the crucible and placed in oven at $105 \mathrm{C}^{\circ}$ for 4 hours. After that it was 
transferred to dessicator for 30 minutes to cool and weighed (W1). Then the crucible placed in a muffle furnace for 4 hours at $550 \mathrm{C}^{\circ}$ burned till white and weighted again (W2). Crude fibre was then calculated. ${ }^{23}$

$\%$ crude fibre $=\frac{\mathrm{W} 2-\mathrm{W} 1}{\text { Weight of sample }} \times 100$

Where

$\mathrm{W} 2-\mathrm{W} 1=$ Crude fiber

$\mathrm{W} 1=$ Weight of sample after placing in oven

W2 = Weight of sample after placing in muffle furnace

\section{Carbohydrates determination:}

Carbohydrates can be determined by adding the weights of all the other contents then subtracted from $100 .^{24}$

$\%$ carbohydrates $=($ crude fibre + crude fat + crude protein + moisture contents+ Ash) -100

\section{Analgesic activity by writhing induced method Requirements}

Acetic acid, plant extract and silver nanoparticles, diclofenac sodium, Albino mice (about 22g b.w), normal saline solution and 3 and $5 \mathrm{cc}$ syringes

\section{Procedure}

The animals were not fed anything for at least 24 hours before the start of the experiment. There was a total of six groups. Group I was treated with diclofenic sodium (10mg/kg b.w, p.o) used as positive control. Group II was treated with normal saline $(10 \mathrm{mg} / \mathrm{kg}$ b.w, i.p) used as negative control. Group III was treated with $100 \mathrm{mg} / \mathrm{kg}$ b.w, i.p of plant extract. Group IV was treated with $200 \mathrm{mg} / \mathrm{kg}$ b.w, i.p of plant extract. Group V was treated with $300 \mathrm{mg} / \mathrm{kg}$ b.w, i.p route of plant extract. Group VI was treated with only acetic acid. After 30 minutes of drug administration such as diclofenac sodium, normal saline solution, plant extract solution to the mice then injected $1 \%$ acetic acid into the peritoneal cavity in order to cause pain. Recorded the writhing (extension of hind limbs, contraction of abdomen and turning of trunk) in the mice after 5, 10 and 15 minutes in various groups. \% inhibition was recorded by using the following formula. ${ }^{25-26}$

Pharmacognostic study of Euphorbia dracunculoides L. was carried out to standardized the quality and quantity of the drug.

\section{RESULTS}

Pharmacognostic studies of Euphorbia dracunculoides L.

Whole plant extract of Euphorbia dracunculoides L. were evaluated for pharmacognostic study i-e Macroscopic, powder drug study, phytochemical analysis, nutritional and elemental analysis.

\section{Macroscopy}

The macroscopic character of the plant Euphorbia dracunculoides L. were observed for odor, shape, taste, colour and texture (Table 1, 2, 3). It helped in the correct identification of the plant. It is an annual herb. Its stem is light green at the top and yellow green at the bottom and $15-30 \mathrm{~cm}$ tall, it is much branched from the base. Its leaves are alternate, sessile, simple, dark green in color, its roots are yellowish in color, conical shape, smooth with rootlets.

\section{Microscopic study}

Powder drug study

Powder drug study of whole plant powder of Euphorbia dracunculoides L. was carried out (Figure 1). It shows different structures in powder form
Table 1: Macroscopic studies of Euphorbia dracunculoides stem

\begin{tabular}{ccc}
\hline S.No & Charactristic & Observation \\
\hline 1 & Color & Yellow green at bottom, light green at top \\
2 & Habit & Annual \\
3 & Taste & Bitter \\
4 & Odor & Odorless \\
5 & Size & 15 to $30 \mathrm{~cm}$ \\
6 & Branching & From the base it is much branched \\
7 & Position & Vertical \\
8 & Latex & Present, white \\
9 & Surface & Glabrous \\
10 & Texture & Smooth \\
11 & Shape & Cylindrical \\
\hline
\end{tabular}

Table 2: Macroscopic studies of Euphorbia dracunculoides Root

\begin{tabular}{ccc}
\hline Root & Characteristic & Observation \\
\hline 1 & Size & $13 \mathrm{~cm}$ \\
2 & Shape & Conical \\
3 & Odor & Cephraceous \\
4 & Taste & Almost tasteless \\
5 & Color & Yellowish \\
6 & Position & Downward \\
7 & Texture surface & Smooth \\
8 & Rootlets & Present \\
\hline
\end{tabular}

Table 3: Macroscopic studies of Euphorbia dracunculoides Leaf

\begin{tabular}{ccc}
\hline S. No & Characteristic & Observation \\
\hline 1 & Size & 1.5- $8 \mathrm{~cm} \times 1.5-5 \mathrm{~mm}$ \\
2 & Petiole & Absent, sessile \\
3 & Phylotaxis & Alternate \\
4 & Taste & Slightly bitter \\
5 & Odor & Odorless \\
6 & Color & Dark green \\
7 & Lamina & Simple \\
8 & Stipule & Stipulated \\
9 & Texture & Soft coriaceous \\
10 & Apex & Acute, subacute or \\
& & obtuse \\
11 & Margin & Entire \\
12 & Venation & Reticulate \\
13 & Surface & Glabrous \\
\hline
\end{tabular}




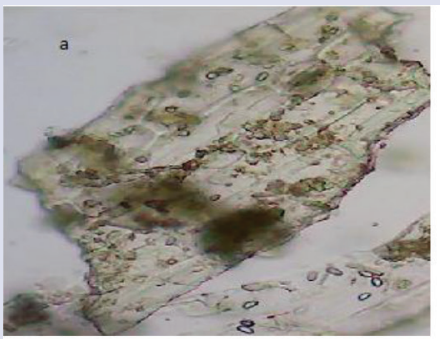

A

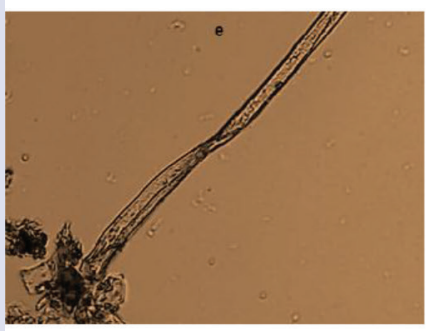

D

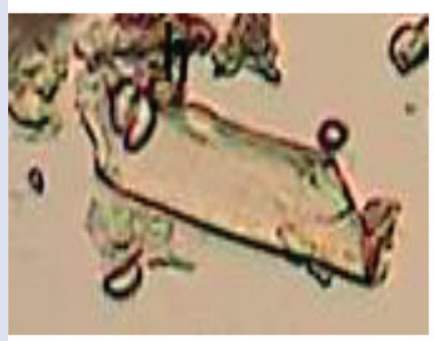

G

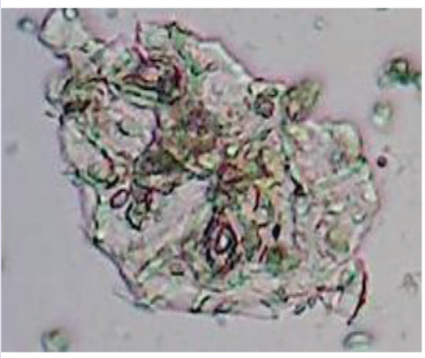

$\mathbf{J}$

Figure 1: Powder drug study of Euphorbia dracunculoides L.

A. Epidermal cells. B. Stomata. C. Multicellular Trichomes. D. E. Phloem Fibers, F. Cortical cells, G. Xylem vessel H. Oil droplets, I. Pollen grain, J. Epidermal cell with stomata, K. Single trichome, L. Starch grains
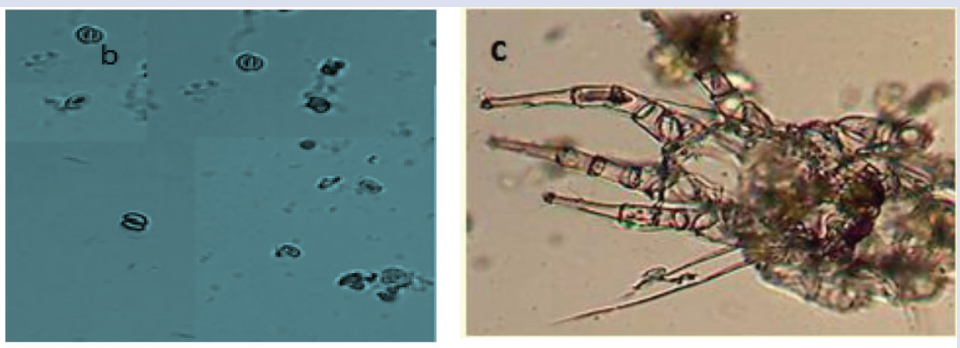

$\mathbf{B}$

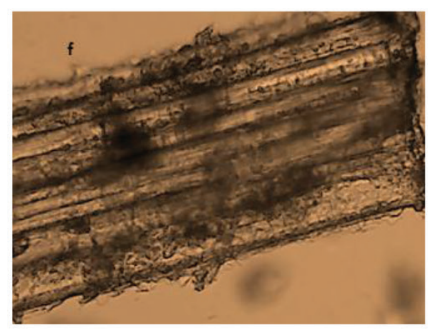

C

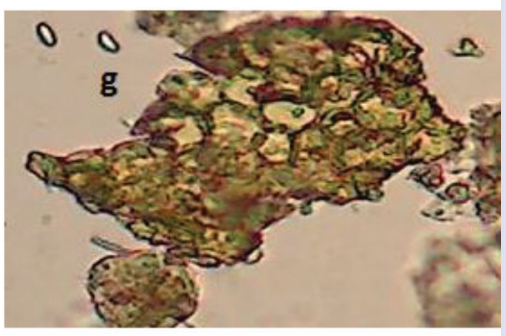

$\mathbf{F}$

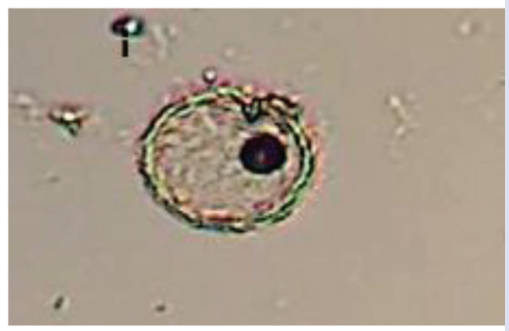

I

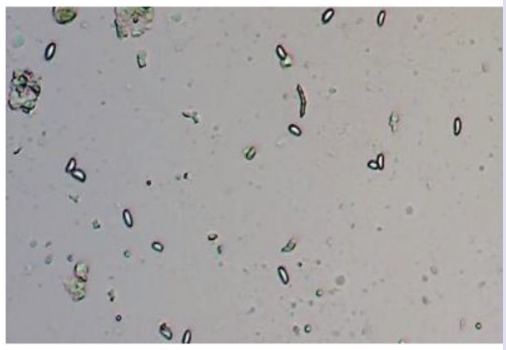

$\mathbf{L}$

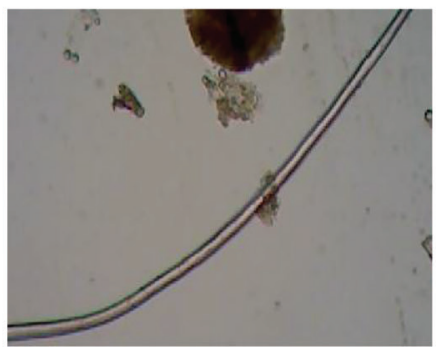

$\mathbf{K}$

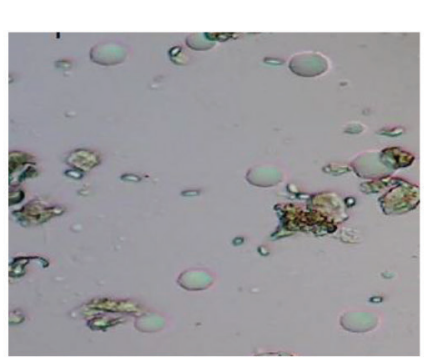

which helps in the authentication and standardization of crude plant extract drug. Following were some of the structures observed under microscope.

- Fragments of epidermal cells

- Stomata

- Xylum vessels

- $\quad$ Phloem fibres
- $\quad$ Single and multicellular trichomes

- Cortical cells

- Starch grains

- Oil droplets

- $\quad$ Epidermal cell with stomata

- Pollen grain 


\section{Phytochemical Analysis.}

Both qualitative and quantitative phytochemical analysis of the ethanolic extract of whole plant Euphorbia dracunculoides L. were carried out. Qualitative analysis of Euphorbia dracunculoides L. revealed the presence of carbohydrates, proteins, flavonoids, phenolic compounds, tannins, alkaloids, glycosides, sterols etc (Table 4).

Quantitative analysis of some of the secondary metabolites such as saponins, flavonoids, tannins and alkaloids were also carried out in the ethanolic whole plant extract of Euphorbia dracunculoides L. The quantitative result revealed the presence of sterols (20.5\%), tanins (18.5\%), saponins (17\%) and alkaloids (10\%). (Table. 5)

\section{Nutritional analysis}

In the present study, the nutritional analysis of Euphorbia dracunculoides L. were carried out and the result presented in the table. 6. Result of proximate analysis of Euphorbia dracunculoides L. showed the highest quantity of fibres $(28.13 \pm 0.7094)$ followed by proteins $(26 \pm 2.6457)$, carbohydrates $(17 \pm 0.5)$, ash $(9.01 \pm 0.015)$, fat (7.1 \pm 0.3605$)$, and moisture contents (14\%).

\section{Elemental analysis}

In the present study, the elemental analysis of Euphorbia dracunculoides L. conducted which showed the presence of both macro and micro nutrients given in the table. 7 .

The concentration of macronutrients i-e Magnesium (2.156 \pm 0.0071$)$, Sodium $(1.032 \pm 0.0034 \mathrm{ppm})$ and $\mathrm{Zn}(0.428 \pm 0.0160)$ while the concentration of micronutrients i-e Iron $(3.043 \pm 0.0168), \mathrm{Cu}(0.088 \pm 0.0036)$, $\mathrm{Ag}(0.008 \pm 0.0036)$ and $\mathrm{Au}(0.347 \pm 0.4262)$ were found in E. dracunculoides L.

Table: 4: Qualitative analysis of Euphorbia dracunculoides L.

\begin{tabular}{|c|c|c|c|}
\hline S.No & Constituents & Test name & $\begin{array}{l}\text { Whole plant } \\
\text { extract }\end{array}$ \\
\hline \multirow[t]{2}{*}{1.} & Carbohydrates & Benedict's Test & + \\
\hline & & Fehling's Test & + \\
\hline \multirow[t]{3}{*}{2.} & Proteins and amino & Ninhydrin Test & + \\
\hline & & Biuret test & + \\
\hline & & Xanthoproteic Test & - \\
\hline \multirow[t]{2}{*}{3.} & Flavonoids & Alkali reagent test & + \\
\hline & & Lead acetate test & + \\
\hline 4. & Saponins & Froth Test & + \\
\hline \multirow[t]{3}{*}{5.} & Alkaloids & Wagner's Test & + \\
\hline & & Hagner Test & + \\
\hline & & Dragon draff's Test & + \\
\hline 6. & $\begin{array}{l}\text { Sterols and } \\
\text { triterpenoids }\end{array}$ & Salkowski test & + \\
\hline 7. & $\begin{array}{l}\text { Tanins and Phenolic } \\
\text { compounds }\end{array}$ & Ferric chloride test & + \\
\hline 8. & Glycoside & Killaerkilani Test & + \\
\hline 9. & Oil & Spot test & - \\
\hline
\end{tabular}

Table 5: Quantitative analysis of Euphorbia dracunculoides L

\begin{tabular}{cccc}
\hline Tanins & Sterol & Saponins & Alkaloids \\
\hline $18.5 \%$ & $20.5 \%$ & $17 \%$ & $10 \%$ \\
\hline
\end{tabular}

\section{Analgesic activity by writhing induced method}

Crude ethanolic extract of Euphorbia dracunculoides at various doses through i.p. route $(100,200,300 \mathrm{mg} / \mathrm{kg}$ b.w) showed decrease in the mean number of writhing in different test groups at different time as shown in the table 8.

After five minutes, In saline treated group mean writhing was $31.66 \pm 1.66$. The percent writhing inhibitory effect produced by different test doses of crude extract of E. dracunculoides L. was $64.21 \%(100 \mathrm{mg} / \mathrm{kg}), 74.73 \%$ $(200 \mathrm{mg} / \mathrm{kg})$ and $95.79 \%(300 \mathrm{mg} / \mathrm{kg})$ compared to saline control. After 10 minutes, in saline treated group the mean writhing was $49 \pm 1.73$, the writhing inhibitory effect of crude extract was $51.02 \%(100 \mathrm{mg} / \mathrm{kg})$, $70.08 \%(200 \mathrm{mg} / \mathrm{kg}), 96.61 \%(300 \mathrm{mg} / \mathrm{kg})$ while after 15 minutes, in saline treated group the mean writhing was $68 \pm 1.15$, the writhing inhibitory effect of crude extract was $53.92 \%(100 \mathrm{mg} / \mathrm{kg}), 66.17 \%(200 \mathrm{mg} / \mathrm{kg})$ and $95.58 \%(300 \mathrm{mg} / \mathrm{kg})$. The effect produced by crude extract was dose dependent. The maximum writhing inhibition was shown by diclophenac sodium at $10 \mathrm{mg} / \mathrm{kg}$ b.w $(99.32 \%)$ and crude extract at $300 \mathrm{mg} / \mathrm{kg}$ (96.61\%). This result showed that the crude plant possess strong analgesic effect.

\section{DISCUSSION}

\section{Macroscopy}

That reduces the wrong recommendations of medicinal plants and traditional medicines to high extent, stepwise pharmacognostic investigations, including morphology, anatomy, quantitative microscopy determination such as stomata number, index, vein islet $r$, veinlet termination number, palisade ratio and qualitative and quantitative phytochemical screening give standardization of the crude drugs. Correct identification, authentication and quality assurance of the preliminary resources as an important requirement to make sure the reproducible quality of phytomedicine which will show the safety and effectiveness of herbal products.

Similar study was also conducted by other researchers. Mughal et al. ${ }^{27}$ studied the phytochemical analysis and pharmacognostic study of, Euphorbia hirta, Euphorbia prostrata, Jatropha integerrima, Ricinus communis and Euphorbia splendens (Family: Euphorbiaceae). Sharma and Pracheta, ${ }^{28}$ carried out the macroscopic and powder drug study of the leaves of the Euphorbia neriiffolia. They observed that the fresh leaves are simple, with leathery texture, dark green in colour, sub-acute apex, acute base, cuneate shaped, entire margins, glabrous surface, reticulate venation. Kumar et al. ${ }^{29}$ evaluated pharmacognostically Euphorbia Hirta plant. The leaves of E. hirta are opposite, oblong or oblong-lanceolate, elliptical, its upper surface is darker, with a faintly toothed margin. Its flowers are numerous, small and about $1 \mathrm{~cm}$ in diameter. Kanthale and Panchal, ${ }^{30}$ evaluated the pharmacognostic study of Adhatoda vasica Nees.

\section{Microscopic study Powder drug study}

Powder microscopy help in the identification of the herbal drugs and detection of adulteration in crude drugs

Similar study was also carried by other researchers; Sharma and Pracheta, ${ }^{28}$ carried out the macroscopic and powder drug study of the leaves of the Euphorbia neriiffolia. Powder drug study revealed the presence of anomocytic stomata, spongy parenchyma, unicerrate multicellular trichomes, xylum parenchyma, starch grains, xylum fibres, epidermal cells. Patil and Jadhav, ${ }^{31}$ carried out the macroscopic and microscopic study of the plant Antidesma acidum Retz. Its powder drug study of leaves showed unicellular trichomes, epidermal cells, phloem fibres, hexagonal sclerenchyma cells, xylem and stomata. Kumar et al. ${ }^{29}$ investigated trichomes, vascular bundles, xylem cells, spongy parenchyma 
Khattak et al.: Pharmacognostic Evaluation of Euphorbia dracunculoides L.

Table 6: Proximate analysis of Euphorbia dracunculoides $\mathrm{L}$.

\begin{tabular}{cccccc}
\hline Ash $\%$ & Carbohydrates $\%$ & Fibers $\%$ & Proteins $\%$ & Fats $\%$ & Moisture $\%$ \\
\hline $9.01 \pm 0.015$ & $17 \pm 0.5$ & $28.13 \pm 0.7094$ & $26 \pm 2.6457$ & $7.1 \pm 0.3605$ & 14 \\
\hline
\end{tabular}

Table 7: Elemental Analysis of Euphorbia dracunculoides L.

\begin{tabular}{ccccccc}
\hline \multicolumn{3}{c}{ Macro-elements $(\mathrm{ppm})$} & \multicolumn{4}{c}{ Micro-elements (ppm) } \\
$\mathrm{Na}$ & $\mathrm{Zn}$ & $\mathrm{Mg}$ & $\mathrm{Fe}$ & $\mathrm{Cu}$ & $\mathrm{Ag}$ & $\mathrm{Au}$ \\
$\mathrm{Mean} \pm \mathrm{SD}$ & Mean $\pm \mathrm{SD}$ & Mean $\pm \mathrm{SD}$ & Mean $\pm \mathrm{SD}$ & Mean \pm SD & Mean $\pm \mathrm{SD}$ & Mean $\pm \mathrm{SD}$ \\
$1.032 \pm 0.0034$ & $0.428 \pm 0.0160$ & $2.156 \pm 0.0071$ & $3.043 \pm 0.0168$ & $0.088 \pm 0.0036$ & $0.008 \pm 0.0036$ & $0.347 \pm 0.4262$ \\
\hline
\end{tabular}

Table 8: Analgesic activity by writhing induced method of Euphorbia dracunculoides

\begin{tabular}{|c|c|c|c|}
\hline \multirow{2}{*}{$\begin{array}{c}\text { Dose } \\
\text { (mg/ } \\
\text { kg,b.w) }\end{array}$} & \multicolumn{3}{|c|}{ Mean number of Writhing \pm SEM ( $\%$ of saline) } \\
\hline & 5 Min & $10 \mathrm{~min}$ & $15 \mathrm{~min}$ \\
\hline \multicolumn{4}{|c|}{ Normal saline } \\
\hline $10 \mathrm{ml} / \mathrm{kg}$ & $31.66 \pm 1.66$ & $49 \pm 1.73$ & $68 \pm 1.15$ \\
\hline \multicolumn{4}{|c|}{ Diclophenac sodium } \\
\hline 10 & $\begin{array}{c}1.33 \pm 1.32 \\
(95.79 \%)\end{array}$ & $\begin{array}{c}0.33 \pm 0.32 \\
(99.32 \%)\end{array}$ & $\begin{array}{c}0.33 \pm 0.32 \\
(99.32 \%)\end{array}$ \\
\hline \multicolumn{4}{|c|}{ Plant extract Euphorbia dracunculoides } \\
\hline 100 & $\begin{array}{c}11.33 \pm 0.66 \\
(64.21 \%)\end{array}$ & $\begin{array}{c}24.66 \pm 3.47 \\
(51.02 \%)\end{array}$ & $\begin{array}{r}31.33 \pm 4.67 \\
(53.92 \%)\end{array}$ \\
\hline 200 & $\begin{array}{c}8 \pm 2.51 \\
(74.73 \%)\end{array}$ & $\begin{array}{c}14.66 \pm 1.20 \\
(70.08 \%)\end{array}$ & $\begin{array}{l}23 \pm 1.52 \\
(66.17 \%)\end{array}$ \\
\hline 300 & $\begin{array}{c}1.33 \pm 0.32 \\
(95.79 \%)\end{array}$ & $\begin{array}{c}1.66 \pm 0.32 \\
(96.61 \%)\end{array}$ & $\begin{array}{c}3 \pm 0.57 \\
(95.58 \%)\end{array}$ \\
\hline
\end{tabular}

and phloem cells in the leaves of Holoptelea integrifolia. Sundar and Pillai, ${ }^{32}$ evaluated the pharmacognostical standards by studying macroscopic and microscopic characters of Solanum virginianum L.

\section{Phytochemical Analysis}

Phytochemicals are actually organic compounds which possess medicinal properties (Mir et al..$^{33}$ Medicinal plants contain some bioactive organic compounds i-e carbohydrates, steroids, tannins, flavonoids, alkaloids and terpenoids, which provide specific physiological action on the human body. Okeniyi et al. ${ }^{34}$ confirmed the presence of reducing sugars, cardiac glycosides, flavonoids, saponins, triterpenes, tannins, steroids, glycosides, carbohydrates and phlobatanins in the stem and leaf extract of Euphorbia heterophylla. Qaisar et al. ${ }^{35}$ studied secondary metabolites of the aerial parts of Euphorbia helioscopia, E. hirta, E. milli and E. prostrate. They showed that these plants contain flavonoids, tannins and terpenoids. Similar study has been carried by other researchers; Pranoothi et al. ${ }^{36}$ carried out the Quantitative analysis of Leucas indica which revealed the presence of total flavonoids and phenols contents in the plant extract. Kumbhar and Godghate, ${ }^{37}$ conducted the qualitative and quantitative analysis of Acacia nilotica bark, Bombax malbaricum flower, Butea monosperma (flower, bark, pod, leaves) and Eucalyptus globulus bark. Subha et al. ${ }^{38}$ carried out the qualitative and quantitative analysis of Tanacetumparthenium L. Among quantitative analysis phenols were found maximum in methanolic extract $(52.01 \mathrm{mg} / \mathrm{g})$ followed by terpenoids $(53.65 \mathrm{mg} / \mathrm{g})$, flavonoids $(19.64 \mathrm{mg} / \mathrm{g})$ and tannin $(16.53 \mathrm{mg} / \mathrm{g})$. Jaradat et al. ${ }^{39}$ studied the quantitative analysis of Ephedra alata. Their result showed the total phenolic and flavonoid contents present in the extract of Ephedra alata.

\section{Nutritional analysis}

Food is the basic need of all living organisms. The basic purpose behind eating is getting calories, maintaining, growing, reproducing and multiplying of cells. A food must have proteins, carbohydrates, lipids, mineral elements, vitamins and water. Proteins, fats and carbohydrates are the most important nutrients of life. Similar studies were conducted by other researchers; Offor et al. ${ }^{40}$ analyzed crude fibre (17.3\%), Ash (3.8\%), moisture (14.8\%), carbohydrates (50.6\%), fat (4.5\%) and protein $(24.5 \%)$ in the dried leaves of moringa. Igwenyi et al. ${ }^{41}$ conducted the Proximate analysis of Euphorbia hyssopifolia which showed the quantity of crude fat (3.20\%), protein $(0.88 \%)$, ash content $(3.80 \%)$, carbohydrate content $(6.98 \%)$, crude fiber (2.15\%) and high moisture content (83.00\%). Ghani et al. ${ }^{42}$ analyzed 4 medicinal plants i-e Achryanthus aspera, Peganum hermala, Mentha longifolia and Solanum nigrum for nutritional study. Offor and Uchenwoke, ${ }^{43}$ examined the proximate analysis of Gongronema latifolium leaves.

\section{Elemental analysis}

Medicinal plants contain Macro and Micro elements that control biochemical processes in the human body. The active ingredients of these plants play an essential role in metabolism. Similar work was also performed by other researchers Saxena et al. ${ }^{44}$ determined the elements in the roots, leaves and stem of Uraria picta. Henry et al. ${ }^{45}$ demonstrated the elemental analysis of Cayratia gracilis (Guill. \& Perr.). Barua et al. ${ }^{46}$ studied the elemental analysis of 5 plants i-e Bryophyllum pinnatum, Corchorous fascicularis, Ocimum sanctum, Acorous calamus and Plantago erosa. Parvez et al. ${ }^{47}$ analyzed the macro minerals i-e Ca, N, P, S, Mg and $\mathrm{K}$ and micro minerals i-e $\mathrm{Zn}, \mathrm{Fe}, \mathrm{Cl}, \mathrm{Mn}, \mathrm{Cu}, \mathrm{Mo}$, Se and $\mathrm{Na}$ in the Euphorbia granulate.

\section{Analgesic activity by writhing induced method}

Analgesia is the sensation of "pain". Usually a deeply unlikable sensation brought about by internal or external stimulation. An analgesic is used to relieve pain without effecting consciousness or eliminating complete sensation. They act on the CNS or the peripheral nervous system. Analgesic activity is the capability of a substance to ease pain. Acetic acid permeates the capillaries which releases endogenous constituents to give rise inflammatory pain by stimulating nerve endings. Similar study was shown by other researchers; Chandrashekar et al. ${ }^{48}$ investigated the analgesic activity of the Phyllanthus lawii. They suggested that the methanolic extract of $P$. lawii reduces the writhing in mice by injecting acetic acid showing peripheral analgesic activity. It releases the pain so it showed excellent analgesic activity. Kadam and Bodhankar, ${ }^{49}$ observed the significant analgesic activity at the dose $400 \mathrm{mg} / \mathrm{kg}$ b.w of the ethanolic 
extract of Entada phaseoloides by performing acetic acid induced pain method. Ramamurthy and Sathiyadevi, ${ }^{50}$ observed the analgesic effect by acetic acid induced writhing method in mice of the plant Indigofera trita. They showed that at the dose $200 \mathrm{mg} / \mathrm{kg}$ and $400 \mathrm{mg} / \mathrm{kg}$ b.w the plant extract are more potent to reduce writhing

\section{CONCLUSION AND RECOMMENDATION}

It is concluded from the present research work that Euphorbia dracunculoides is an erect glabrous annual or sometimes perennating herb. The powder microscopy revealed presence of various type of tissues that is a tool for the determination of adulterants in crude powder of E. dracunculoides available in herbal market. Qualitative analysis revealed the presence of carbohydrates, proteins, flavonoids, phenolic compounds, tannins, alkaloids, glycosides, sterols and saponins etc. The quantitative result of Euphorbia dracunculoides L. revealed the presence of highest amount of sterols (20.5\%). The result of elemental analysis showed highest concentration of macronutrients i-e Magnesium while the highest concentration of micronutrients i-e Iron (3.043 \pm 0.0168$)$. Analgesic activity of Euphorbia dracunculoides L. by writhing induced method showed excellent analgesic effect at $300 \mu \mathrm{g} / \mathrm{ml}$. Hence it is recommended that further advance and high level work should be done on E. dracunculoides to use it as a natural, economic and safe drug instead of synthetic haphazard medicines.

\section{CONFLICT OF INTEREST}

All the authors declare no conflict of interest.

\section{REFERENCES}

1. Adnan M, Hussain J, Shah MT, Shinwari ZK, Ullah F, et a I Proximate and nutrient composition of medicinal plants of humid and sub-humid regions in North-west Pakistan. Journal of Medicinal Plants Research. 2010;4(4):339-45.

2. AOAC (Association of Official Analytical Chemists). Official methods of analysis Gaithersburg, MD, Washington, USA. 2000

3. Aruoma OI. Methodological considerations for characterizing potential antioxidant actions of bioactive components in plant foods. Mutation Research/ Fundamental and Molecular Mechanisms of Mutagenesis. 2003;523:9-20. https://doi.org/10.1016/S0027-5107(02)00317-2

4. Chowdhury JA, Islam SI, Sk A, Islam MK. Antibacterial and cytotoxic activity screening of leaf extracts of Vitex negundo (Fam: Verbenaceae). Journal of Pharmaceutical Sciences and Research. 2009;1(1):103-8

5. Dey M. Ripoli C. Pouleva R. Dorn R. Aranovich I. Zaurov D. Kurmukov A. Eliseyeva I. Belolipov A. Akimaliev I. Sodombekov D. Akimaliev MA. Raskin L. Plant extracts from Central Asia showing antiinflammatory activities in gene expression assays. Phytother Res. 2008;22:929-34. https://doi.org/10.1002/ptr.2427; PMid:18350517.

6. Evans WC. Pharmacognosy. $15^{\text {th }}$ ed. English Language Book, Society Baillere Tindall, Oxford University Press. 2002.

7. Harnborne JB. Phytochemical methods ( $3^{\text {rd }}$ Edn). Chapman and Hall, New York. 1998.

8. Huang X, Gao W, Zhao W, Zhang T, Xu J. Flavone and steroid chemical constituents from rhizome of Paris axialis. Zhongguo Zhong yao za zhi= Zhonggue zhongyao zazhi=. China Journal of Chinese Materia Medica. 2010;35(22):29948. PMid:21355268.

9. Joo NS, Kim SM, Jung YS, Kim KM. Hair iron and other minerals' level in breast cancer patients. Biological Trace Element Research. 2009;129(1-3):28-35. https://doi.org/10.1007/s12011-008-8281-x; PMid:19043675.

10. Kadam PV, Yadav KN, Narappanawar NS, Shivatare RS, Bhusnar HU, Patil MJ. Development of Quality standards of Terminalia catappa leaves. Pharmacognosy Journal. 2011;3(26):19-24. https://doi.org/10.5530/pj.2011.26.4.

11. Kargıoglu M, Cenkci S, Serteser A, Evliyaoglu N, Konuk M, et al. An ethnobotanical survey of inner-West Anatolia, Turkey. Human Ecology. 2008;36(5):763-77. https://doi.org/10.1007/s10745-008-9198-x.

12. Kolasani A, Xu H, Millikan M. Evaluation of mineral content of Chinese medicinal herbs used to improve kidney function with chemometrics. Food Chemistry. 2011;127(4):1465-71. https://doi.org/10.1016/j.foodchem.2011.01.106.

13. Kolasani A, Xu H, Millikan M. Evaluation of mineral content of Chinese medicinal herbs used to improve kidney function with chemometrics. Food Chemistry. 2011;127(4):1465-71. https://doi.org/10.1016/j.foodchem.2011.01.106.

14. Kulkarni SK. Handbook of Experimental Pharmacology. $3^{\text {rd }}$ rev. ed. New Delhi: Vallabh Prakashan: 1999; 123-25.
15. Kumar D, Kumar K, Kumar S, Kumar T, Kumar A, Prakash O. Pharmacognostic evaluation of leaf and root bark of Holoptelea integrifolia Roxb. Asian Pacific Journal of Tropical Biomedicine. 2012;2(3):169-75. https://doi.org/10.1016/ S2221-1691(12)60036-7.

16. Merrill. AL. Watt BK. Energy value of foods, basis and derivation. United States Department of Agriculture Handbook 74. USDA, Washington, DC.1973; Pp244.

17. Mondal S, Raja S, Prasad PN, Suresh P. Investigations of phytochemical analgesic, anti-inflammatory and antipyretic effects of Ixora pavetta Andrews leaf. Journal of Nepal Pharmaceutical Association. 2015;27(1):20-7. https://doi. org/10.3126/jnpa.v27i1.12146.

18. Muhammad N, Saeed M, Gilani SN. Analgesic and anti-inflammatory profile of $n$-hexane fraction of viola betonicifolia. Tropical Journal of Pharmaceutical Research. 2012;11(6):963-9.

19. Nisar M, Tariq SA. Nutritional levels of Indigofera gerardiana Wall and Crataegus songrica K. Koch. Pakistan Journal of Botany. 2009;41(3):1359-61.

20. Obadoni BO. Ochuko PO. Phytochemcial studies and comparative of Nigeria. Glo Jou Pure App Sci. 2001;7(3):455-9.

21. Rahman MA, Mossa JS, Al-Said MS, Al-Yahya MA. Medicinal plant diversity in the flora of Saudi Arabia 1: a report on seven plant families. Fitoterapia. 2004;75(2):149-61. https://doi.org/10.1016/j.fitote.2003.12.012; PMid:15030919.

22. Shreedhara CS, Vaidya VP, Vagdevi HM, Latha KP, Muralikrishna KS, et al. Screening of Bauhinia purpurea Linn. for analgesic and anti-inflammatory activities. Indian Journal of Pharmacology. 2009:41(2):75. https://doi.org/10.4103/02537613.51345; PMid:20336222 PMCid:PMC2841237.

23. Van Buren JP, Robinson WB. Formation of complexes between protein and tannic acid. Journal of Agricultural and Food Chemistry. 1969;17(4):772-7. https://doi.org/10.1021/jf60164a003.

24. Wallis TE. Text book of pharmacognosy. $5^{\text {th }}$ ed. CBS Publisher and Distributors New Delhi.2009.

25. Wallis TE. Text Book of Pharmacognosy. CBS publishers, Delhi, 2005; pp 572- 575 PMid:15961988.

26. Yadav RN, Agarwala M. Phytochemical analysis of some medicinal plants. Journal of Phytology. 2011;3(12)

27. Mughal T. Mamona A. Saddiuge Z. Qureshi S. Mehboob S. Phytochemical And Pharmacognostical Evaluation of Euphorbiaceae Species From Lahore Region, Pakistan. J App Pharm. 2010; 3(2):79-85.

28. Sharma V. Microscopic studies and preliminary pharmacognostical evaluation of Euphorbia neriifolia L. leaves.

29. Kumar S. Sutar A. Kumar R. Sutar S. Sonkar S. Pharmacognostical Characterization on the Leaves of Euphorbia hirta (Family: - Euphorbiaceae). Ind Res Pharm \& Sci. 2014;1(2):10-16

30. anthale, PR. Panchal VH. Pharmacognostic Study of Adhatoda vasica Nees. Biosci Discov. 2015.6(1):49-53

31. Patil $P$, Jadhav V. Pharamacognostical Evaluation of Antidesma acidum RETZ. Leaf: A Wild Edible Plant. J Adv Sci Res. 2014;5(1):28-31.

32. Sundar S. PillaiYJK. Pharmacognostic And Physicochemical Evaluation Of Solanum virginianum L Leaves (Solanaceae). Int J Pharm Bio Sci. 2016;7(1):40-4.

33. Mir MA, Sawhney SS, Jassal MM. Qualitative and quantitative analysis of phytochemicals of Taraxacum officinale. Wudpecker Journal of Pharmacy and Pharmacology. 2013;2(1):01-5

34. Okeniyi SO, Garba S. Phytochemical Screening, Cytotoxicity, Antioxidant and Antimicrobial Activities of Stem and Leave Extracts of Euphorbia heterophylla. Journal of Biology and Life Science. 2012;4(1)

35. Qaisar M. UddinGilani SN. Faroog S. Rauf A.Naz R. Shaista R. Perveez S. Preliminary Comparative Phytochemical Screening of Euphorbia Species. American-Eurasian J Agric and Environ Sci 2012;12(8):1056-1060.

36. Pranoothi EK. Narendra K. Suman DSD. Joshi J. Swathi KM. Sowjanya KVN. Rathnakarreddi SS. Emmanuel SJ. Padmavathi C. Satya AK. Studies on qualitative quantitative, phytochemical analysis and screening of in vitro biological activities of Leucas indica (L) var. Nagalapuramiana. Int J Herb Med. 2014;2(3):30-6.

37. Kumbhar RR. Godghate AG. Physicochemical and Quantitative Phytochemical Analysis of Some Medicinal Plants In And Around Gadhinglaj. Int J Sci Envir Technol. 2015;4(1):172-7

38. Subha D. Chandralega N. Geetha. N. Phytochemical Screening of Tanacetum Parthenium L. (Feverfew) Leaves: An Important Medicinal Plant. ljppr Human. 2015;2(2): 98-106

39. Jaradat N, Hussen F, Al Ali A. Preliminary Phytochemical Screening, Quantitative Estimation of Total Flavonoids, Total Phenols and Antioxidant Activity of Ephedra alata Decne. J Mater Environ Sci. 2015;6(6):1771-8.

40. Offor I, Ehiri R, Njoku C. Proximate nutritional analysis and heavy metal composition of dried Moringa oleifera leaves from Oshiri Onicha LGA, Ebonyi State Nigeria. IOSR Journal of Environmental Science, Toxicology and Food Technology. 2014;8(1):57-62. https://doi.org/10.9790/2402-08115762.

41. Igwenyi IO, Agwor AS, Nwigboji IU, Agbafor KN, Offor CE. Proximate Analysis, Mineral and Phytochemical Composition of Euphorbia hyssopifolia. Steroids. 2014;18:6-27.

42. Ghani A, Ali Z, Islam T, Sanaullah S, Saeed S. Nutrient evaluation and elementa analysis of four selected medicinal plants of soon valley Khushab, Punjab, Pakistan. 
Pakistan Journal of Pharmaceutical Sciences. 2014;27(3). PMid:24811823.

43. Offor CE. Uchenwoke IO. Phytochemical Analysis and Proximate Composition of the Leaves of Gongronema latifolium. G J Pharma. 2015;9(2):159-62.

44. Saxena HO, Soni A, Mohammad N, Choubey SK. Phytochemical screening and elemental analysis in different plant parts of Uraria picta Desv.: A Dashmul species. Journal of Chemical and Pharmaceutical Research. 2014;6(5):756-60.

45. Henry EO, Jemilat IA, Kudirat MB, Uche EO, Samuel OE. Phytochemical, Pharmacognostic and Elemental Analysis of Cayratia gracilis (Guill. \& Perr.) Suesseng.

46. Barua CC, Bora M, Saikia BN, Hazarika N, Barua IC. Quantitative Analysis of Proximate and Mineral Composition of a Few Important Medicinal Plants Of
North East Region. IJABPT. 2015;6(3):188-93.

47. Parvez M, Hussain F, Ahmad B, Ali J. Euphorbia granulata Forssk as a source of mineral supplement. Am Eurasian J Agric Environ Sci. 2013;13(8):1108-3.

48. Chandrashekar KS, Saha S, Subraya PK. Analgesic Activity of Phyllanthus lawii Extract in Swiss Albino Mice. Pharmaceutical Crops. 2011;2:8-10. https://doi.or g/10.2174/2210290601102010008

49. Kadam P, Bodhankar SL. Analgesic and Anti-Inflammatory Activity of Seed Kernel Extracts of Entada Phaseoloides Merrill. Int J Pharm Sci. 2014;6(2):477-81.

50. Ramamurthy V. Sathiyadevi M. Anti-Inflammatory and Analgesic Activities of Methanol Extract of Indigofera trita Linn. Int J PI A and Env Sci. 2015;5(4):9-13.

\section{GRAPHICAL ABSTRACT}

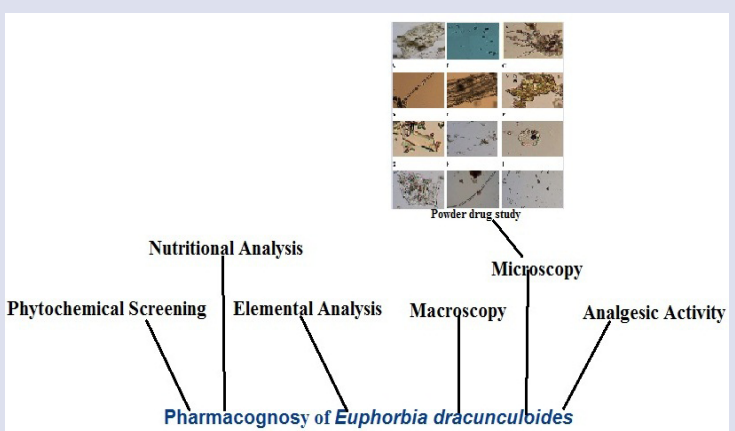

\section{HIGHLIGHTS OF PAPER}

- Pharmacognostic Evaluation and Analgesic Efcacy of Ethanolic Extract of Euphorbia dracunculoides L

- Macroscopic study.

- Powder drug study.

- Phytochemical screening includes both qualitative and quantitative analysis.

- Proximate analysis showed proteins, crude fat, crude fbre, carbohydrates, moisture contents and ash.

- Analgesic activity using Acetic acid induced writhing.

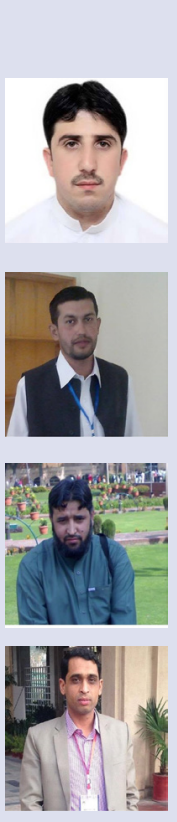

\section{AUTHOR PROFILE}

Shafqat Ali Khan: Ph.D. Scholar Department of Botany, Islamia College Peshawar, Pakistan.

RehmanUllah: Assistant Professor Department of Botany, University of Peshawar, Pakistan.

Barkatullah: Assistant Professor Department of Botany, Islamia College Peshawar

Sami Ullah: Assistant Professor Department of Botany, University of Peshawar, Pakistan.

Umbreen Khattak: Ph.D. Scholar Department of Botany, Islamia College Peshawar, Pakistan.

Cite this article : Khattak WU, Rehmanullah, Khan SA, Barkatullah, and Ullah S. Pharmacognostic Evaluation and Analgesic Efficacy of Ethanolic Extract of Euphorbia dracunculoides L.. Pharmacog J. 2017;9(5):644-53. 